\title{
Interest rates and efficiency in medieval wool forward contracts
}

Article

Accepted Version

Bell, A. R., Brooks, C. and Dryburgh, P. R. (2007) Interest rates and efficiency in medieval wool forward contracts. Journal of Banking \& Finance, 31 (2). pp. 361-380. ISSN 0378-4266 doi: https://doi.org/10.1016/j.jbankfin.2006.04.006 Available at https://centaur.reading.ac.uk/20495/

It is advisable to refer to the publisher's version if you intend to cite from the work. See Guidance on citing.

Published version at: http://dx.doi.org/10.1016/j.jbankfin.2006.04.006

To link to this article DOI: http://dx.doi.org/10.1016/j.jbankfin.2006.04.006

Publisher: Elsevier

All outputs in CentAUR are protected by Intellectual Property Rights law, including copyright law. Copyright and IPR is retained by the creators or other copyright holders. Terms and conditions for use of this material are defined in the End User Agreement.

\section{www.reading.ac.uk/centaur}

\section{CentAUR}

Central Archive at the University of Reading

Reading's research outputs online 
NOTICE: this is the author's version of a work that was accepted for publication in the Journal of Banking and Finance. Changes resulting from the publishing process, such as peer review, editing, corrections, structural formatting, and other quality control mechanisms may not be reflected in this document. Changes may have been made to this work since it was submitted for publication. A definitive version was subsequently published in the Journal of Banking and Finance, 31.2 (2007), DOI: 10.1016/j.jbankfin.2006.04.006 


\title{
Interest Rates and Efficiency in Medieval Wool Forward Contracts
}

\author{
Adrian R Bell \\ ICMA Centre \\ University of Reading
}

\author{
Chris Brooks* \\ Cass Business School
}

\author{
Paul Dryburgh \\ Kings College London
}

\begin{abstract}
While it is commonly believed that derivative instruments are a recent invention, we document the existence of forward contracts for the sale of wool in medieval England around 700 years ago. The contracts were generally entered into by English monasteries, who frequently sold their wool for up to twenty years in advance to mostly foreign and particularly Italian merchants. Employing a unique source of data collected by hand from the historical records, we determine the interest rates implied in these transactions and we also examine the efficiency of the forward and spot markets. The calculated interest rates average around $20 \%$, in accordance with available information concerning the interest rates used in other types of transactions at that time. Perhaps surprisingly, we also find little evidence of informational inefficiencies in these markets.
\end{abstract}

April 2006

Keywords: Wool market, forward contracts, market efficiency, Medieval England, interest rates.

JEL Classifications: G13, N13, N53.

\footnotetext{
* Corresponding author. Faculty of Finance, Cass Business School, City University, 106 Bunhill Row, London EC1Y 8TZ, UK. t: (+44) (0) 207040 5168; f: (+44) (0) 207040 8881; e-mail C.Brooks@ @ity.ac.uk .

The authors gratefully acknowledge financial support for this research from the ESRC under grant RES-000-22-0647. We would like to thank an anonymous referee for useful comments that improved the quality of this paper. We would also like to acknowledge the helpful suggestions of Joelle Miffre and participants of the Conference on banking, credit and finance in late-medieval and renaissance Europe, Queen Mary, University of London, September 2004. The usual disclaimer applies.
} 


\section{Introduction}

It is widely believed that derivative instruments such as forward contracts and options are recent inventions despite evidence to the contrary. The first official exchange for trading contracts for forward delivery, the Royal Exchange (which later became the London Commodity Exchange), was formed in 1570 as a place where metal traders could come together. A formal futures exchange occurred in the late seventeenth century in the Japanese rice markets. Whilst the US has now become the world's largest centre for derivatives trading, the first forward contract in the US (on corn) was not written until 1851 following the formation of the Chicago Board of Trade (CBOT) in 1848. ${ }^{1}$ Kairys and Valerio (1997) discuss a highly developed options market that existed for a brief period in New York between 1873 and $1875^{2}$

However, an examination of the appropriate historical documents demonstrates the existence of quite sophisticated financial instruments much earlier - for example, in England in the Middle Ages. Within the historical literature, there is an ongoing revisionism regarding the sophistication of medieval financial transactions. Many of the financial instruments employed were motivated by the illegality of interest payments on loans (usury) at that time, creating a need for relatively complex transactions that paid an implicit interest. For example, Knoll (2004) suggests that landowners would sometimes transfer the legal title of their property to a "financier" in exchange for cash. The financier would earn a profit by collecting any rents or profits that accrued to the holder of the land, and the original landowner had the right to reclaim the land at the original price on a pre-specified date. Knoll shows that such an arrangement effectively uses an options-based approach and the putcall parity relation to artificially create the same contingent payoffs as a loan secured on property. Both puts and calls were written on tulip bulbs in Amsterdam in the 1600's.

\footnotetext{
${ }^{1}$ See for example, Kroll and Paulenoff (1993).

${ }^{2}$ For further description of the history of futures exchanges and related markets, see Bakken $(1960,1966)$ or Swan (2000).
} 
Not only options, but also instruments akin to forward contracts were in widespread use in the thirteenth and fourteenth centuries. For instance, Italian merchant societies, most notably the Bardi and the Peruzzi of Florence engaged in forward exchange rate agreements for papal taxes collected in England. ${ }^{3}$ Advance contracts for the sale of wool have been identified by Power (1941, p.43), ${ }^{4}$ linking production of wool in English monasteries with Italian merchant bankers. The monasteries frequently sold their wool up to twenty years in advance for prices agreed on the date that the contract was signed.

The objective of our study is to use valuation techniques from "modern" finance theory to analyse a large number of advance contracts for the sale of wool that are documented from the thirteenth century. To our knowledge, this is the first study to comprehensively examine the information contained in a large number of these advance contracts for the sale of wool, and the first to consider the efficiency of this market. Specifically, we conduct two separate pieces of empirical analysis. We first use discounted cashflow analysis to calculate the implied interest rates for these transactions. Second, we examine the efficiency of the wool market by determining whether there is any lagged information from the spot or forward markets that can be used to predict the next period forecast error. To anticipate our main findings, this study adds to the growing literature documenting the financial sophistication of the medieval economy, demonstrating that plausible rates of interest were charged and that the wool market appears to have been informationally efficient.

The remainder of this paper is organised as follows. Section 2 offers some background on the medieval English wool market in order to put our data and study into context. Section 3 discusses the sources of data, while Section 4 describes the financial methodology employed. Finally, Sections 5 and 6 present the results and offer concluding comments respectively.

\footnotetext{
${ }^{3}$ Goldthwaite (1985) and Kohn (1999).

${ }^{4}$ Although Eileen Power's work on the wool trade is seminal in this field, such contracts had already been identified and discussed by Whitwell (1904), Bigwood (1930) and Denholm-Young (1937, pp. 55-57).
} 


\section{The English Medieval Wool Market}

The wool market was extremely important to the medieval English economy. Wool dominated the English export trade from the late thirteenth century to its decline in the late fifteenth century. Contemporary fourteenth-century opinion recognised the significance of the wool trade - naming it 'the jewel of the realm'. Its importance is demonstrated in the often quoted statement by Postan (1973, p.342) that, 'The barons of England, sitting in Parliament, asserted in 1297 that wool represented half of England's wealth or, as they put it, 'half the value of the whole land'. Other illustrations of the pivotal role of wool in medieval finances include the massive ransom of Richard the Lionheart, paid with 50,000 sacks of English wool, and the anachronism of the Chancellor of the Exchequer sitting on the Woolsack in the House of Lords, as the symbolic recognition of his power.

By the end of the thirteenth century, the heavily industrialised areas of Europe could not have existed without exports of English wool to support expanding trade in, particularly, luxury cloths. A halt in the export trade by Edward III in 1337 as part of his 'Wool Company' scheme brought whole areas of the Low Countries to the brink of starvation and economic ruin. ${ }^{5}$ Indeed, it is possible that such protectionist policies, introduced to finance war, ended the sophisticated and early use of forward contracts in the late thirteenth century between Cistercian monasteries in England and Italian merchant bankers. That some of these bankers were subsequently bankrupted has been widely documented and some of the blame has been controversially levelled at Edward III. $^{6}$

The peak of the export trade in wool was during the late thirteenth and early fourteenth centuries with perhaps 40-45,000 sacks exported each year, gradually declining to around 33,000 sacks in

\footnotetext{
${ }^{5}$ This was part of a speculative structured wool deal to finance Edward III's alliance strategy to the tune of $£ 200,000$, CPR 1334-38, pp. 480-2. For the best treatment of the English Wool Company, see Fryde (1988, chapters 6 and 7).

${ }^{6}$ See Hunt (1990).
} 
1355 and only 9,706 sacks in $1476 .^{7}$ The crown's decision to tax the export of wool encouraged (deliberately or not) the development of a domestic cloth industry and thus a move to the export of cloth. This domestic cloth industry was further strengthened by the immigration of Flemish cloth weavers, who perhaps kick-started the growth of the textile industry in England. It could indeed be claimed that wool was at the forefront of the establishment of England as a European political and economic power.

\section{Sources of Data, Contract Details and Wool Pricing}

The unique data employed in this study are the details of recorded contracts between sheep farmers and, generally, foreign merchants seeking wool to export for textile manufacture. Information from over 220 contracts has been collected from The National Archives for the period $1200-1330$, although the vast majority was enrolled between 1270 and 1310. Simple registrations of debt and more complex arrangements are found in the Memoranda Rolls of the Exchequer, longer, more detailed contracts in the Close Rolls of the Chancery, while the Plea Rolls of the Exchequer detail disputes over, and attempted resolution of, instances of default. Most contracts were written in medieval Latin, though a handful survive in medieval French. A sample translated contract follows:

\section{TNA E159/60, rot. $18^{8}$}

12 May 1287

Recognisance of the abbot of Meaux.

He came before the exchequer court and recognised for himself, his convent and his successors that he was bound to Ricardo and Reynerio Guidicionis, Henrico de Podio and Thomasino Guidicionis, and their fellow merchants of Lucca, in eleven sacks of the better wool of his house, pressed and packed into round bales and weighed according to the ancient custom of the hou se, to be delivered to the merchants in the quindene of the Nativity of St John the Baptist [8 July] 1289 in Hull, packed into the sarplers of the abbot and convent. For which wool the abbot acknowledged he had received the full price in advance, which is to say 15 marks per sack. And if the abbot cannot deliver the said wool to the merchants at the specified term, he agrees for himself, his convent and for his successors as abbot that the exchequer might levy the wool or its value from the lands, tenements, goods and chattels of the house.

The contracts are highly detailed ${ }^{9}$ and give information on the purchaser and seller, the quality and amount of wool to be delivered, the due dates for delivery, and the amount of money per sack to be

\footnotetext{
${ }^{7}$ Lloyd, (1977, p.311, Table 19). For a summary of exports, see Carus-Wilson, and Coleman (1963), especially the table, "England: Raw Wool Exports", pp. 122-123.

${ }^{8}$ All of the contracts under discussion are available at The National Archive (TNA) Kew, London. They are now published in transcription and parallel English translation, see Bell et al (2006) and online at the UK Data Archive (www.data-archive.ac.uk), study number: 5325.
} 
paid, together with information on any advance and miscellaneous payments. Contracts could remain in force from just a few months to as long as twenty years. In total, they record arrangements for the delivery of around 5500 sacks of wool between both a small number of individual, lay producers and all of the major monastic orders (though the Cistercians predominate, contracting for exactly half of the total wool sold) and wool merchants from England, France, Flanders, Germany, Spain, and, most especially, the Italian city states of Florence, Genoa, Lucca, Piacenza, and Pistoia. The contracts were individually tailored by the counterparties since no formalised secondary market existed, and thus these are forward agreements of sorts rather than futures contracts.

\subsection{Why were these agreements formed and what was the nature of them?}

It is of interest to examine the motivations that each counterparty would have had to enter into the agreement. For the monasteries, their gains from the contract could be twofold. First, they would have known in advance how much money they would obtain for their wool for several years into the future, which would have enabled them to plan financially. Second, and almost certainly more importantly, they obtained large up front payments that could be put to immediate use for building works and the dual burden of royal and papal tax payments. Even though they were theoretically very wealthy in terms of their assets, many monasteries found themselves in dire financial straits, with large debts, and they were therefore in desperate need of cash.

All merchants were keen to ensure a continual supply of high quality wool to fuel cloth production in the rapidly expanding urban, industrial centres of Flanders and northern Italy. Italian societies, in particular, sought out, and had the capacity to pay very high prices for, the highest quality wools,

\footnotetext{
${ }^{9}$ It should be stated at the outset that any study of medieval source data from a modern finance perspective is fraught with difficulty. The techniques that are in common usage today for the pricing of financial assets can typically rely on large quantities of readily accessible data of high quality. However, the records that were kept in the Middle Ages were far from complete, and there was no international standard in terms of wool quality, quantity or even exchange rates, all of which combine to make comparisons across different transactions difficult. For example, Lloyd (1973, p.2), argues that, "a stone ... might weigh almost anything from 6 to 28 pounds". Therefore, the calculations performed below will necessarily require a number of assumptions that would be unnecessary for research using modern data.
} 
committing their financial resources to producers over prolonged periods to secure them. Just two societies, the Riccardi of Lucca and the Frescobaldi of Florence, for instance, took over $50 \%$ of the total contracted wool, investing around $£ 20000 .{ }^{10}$ In 1294 , moreover, Italian merchants were buying from 49 out of the 74 Cistercian monasteries, which produced the best grade wool.

Through the contracts, we would anticipate that the merchants should typically receive the wool at a significant discount compared to the prices prevailing at that time. ${ }^{11}$ Ignoring any time value of money, the average value per sack of wool specified in the contracts is some $20 \%$ lower than the monks would have received if they sold their wool at the prevailing price at the time that the contract was signed. Of course, this average figure masks enormous variations (a standard deviation of $22 \%$ ) in the differences across contracts. An extreme example is where William, Abbot of Flaxley (Gloucs.), contracted on 21 November $1281^{12}$ to sell 8 sacks of wool (6 of good wool, 1 of middle wool and 1 of locks) for delivery on 9 July 1291 to Thomas de Basinges, citizen of London. The prevailing price for good wool at that time was 4,178d, but the abbot received only $1,120 \mathrm{~d}$, representing a $73 \%$ discount, although the contract suggests that there had been postponement of an earlier delivery. As one would expect, previous default seems to reduce the amount that an abbot could expect to receive for his wool by selling it in advance. Examining only those contracts where there is renegotiation following default, the typical discount relative to the market price rises to $27 \%$.

Examining the size of these discounts is simply another way of looking at the large interest payments that the merchants received on their loans to the monasteries. Although it is impossible to separate the impact of the quality of wool from the implicit loan interest (aside from information on the broad quality categorisations described below), given the vast differences between the

\footnotetext{
${ }^{10}$ And this represented only a fraction of their total outlay in trading operations in England.

${ }^{11}$ We would also expect that the prices would be lower than if they had waited and bought it on a year-by-year basis, a situation akin to normal backwardation of the forward prices.

${ }^{12}$ TNA E $159 / 55$, rot. 6 .
} 
prevailing market prices and the prices that the abbots received by selling in advance, it cannot be said that the merchants were paying over the odds for their wool.

Another interesting feature of the majority of contracts is that, no matter what their duration, the payments per sack for a given grade of wool remained fixed. For example, the agreement enrolled on 29 September 1298 between Abbot Adam of Combermere (Cheshire) and the Frescobaldi stipulated that four sacks of good wool would be delivered annually on 8 July for twenty years for a fixed price of $£ 9.6 \mathrm{~s} .8 \mathrm{~d}$ per sack. ${ }^{13}$ One possible explanation for the fact that the prices per sack specified in the contract do not increase over the lifetime of the contract is that these amounts per sack were purely notional figures "for the records". That is, the merchant had said, "I will pay you the sum of $£ 500$ now, and I want to receive five sacks of good wool per year for the next ten years”. It would not matter whether the contract stipulated that the sacks were all worth $£ 10$, or whether they were worth $£ 8$ per sack for the first five years and $£ 12$ thereafter. Thus fixing the amounts specified per sack as fixed through time was done purely for mathematical simplicity.

An alternative explanation is that wool prices had no predictable patterns or trends, and the counterparties were aware of this and set the contract details accordingly. A plot of wool prices over the period ${ }^{14}$ demonstrates the stability of the prices within the contracts stands in stark contrast to the highly volatile series of actual wool prices. Therefore it was sensible, when viewed ex post, for both parties to assume that prices would not rise over the contract period.

Some summary statistics for the mean annual wool prices from Lloyd for the period $1275-1322$ (47 observations) are presented in Table 1. As can be seen from the table, the average wool price was $£ 4.62$, with a standard deviation of $£ 0.76$. The series is positively skewed and is slightly

\footnotetext{
${ }^{13}$ TNA E $159 / 72$, rot. 45 . Note that there is no conflict with the notion of normal backwardation here since there was no secondary market for these forward contracts and therefore no expectation that the forward price will move towards the spot price as maturity approaches.

${ }^{14}$ Not shown due to space constraints but available from the authors on request.
} 
leptokurtic. While the series is persistent, with first and second order autocorrelation coefficients of around 0.75 , the raw price series is just stationary at the conventional significance level according to a Dickey-Fuller test.

\section{Methodology}

\subsection{Calculating the Interest Rate for the Wool Transactions}

A first issue is the question as to whether the advance wool contracts are best analysed as forwards or loans. ${ }^{15}$ Eldridge and Maltby (1992) have investigated one particular thirteenth century contract between Fountains Abbey and a group of Florentine merchants for the advance sale of wool, arguing that this is equivalent to a modern forward contract. As they point out, these agreements certainly have many of the characteristics of forward contracts as the term would be understood by financial market practitioners - they are an agreement for the purchase/sale of a particular quantity of wool of specific quality grade. The dates and places where the wool will be delivered, and the payment schedule are also specified meticulously in the contracts.

However, most historians would argue that such transactions were in fact loans in disguise, motivated by the illegality of usury (interest) at that time. The key point appears to be that no money would change hands on the contract signing date in the case of a forward contract, but the monasteries often received large up-front payments. Many of the contracts that we have uncovered make explicit references to up-front payments, indicative of a loan feature in the transaction. Even for contracts where no explicit mention of any advance payments is made in the contracts, this does not necessarily imply that there were none since the details of the transaction were sometimes not fully recorded. Equally, these agreements are not pure loans since the "repayment" was in wool rather than cash. Thus we conjecture that the transactions have both loan and forward contract

\footnotetext{
${ }^{15}$ Williams (1986, Chapter 2) argues that a conventional short hedge, where an agent purchases a commodity spot and sells the commodity for future delivery on a futures exchange is equivalent to borrowing the commodity and lending money. This is essentially a type of repurchase agreement, where the forward contract can be interpreted as a loan. We are grateful to an anonymous referee for bringing this to our attention.
} 
features, and given the kind of data available, it appears impossible to separate the two parts. Thus we are able to calculate a rate of interest implied in the transaction, which will be a composite rate made up of both loan interest and the cost of carry.

The core formulae for valuing futures on commodities are the cost of carry relations, which stipulate that the fair price to pay today for delivery of the commodity in the future is equal to the spot price adjusted for the cost of storage of the commodity plus the cost of funding it. In theory, for the case of wool forwards, there is also a "convenience yield" to consider, since physical ownership of the wool would have been valuable in case of wool shortages during the lifetime of the contract. If shortages are deemed likely, the convenience yield will be high, although if merchants have large inventories, this yield will be small. Thus the relationship between spot and forward prices for wool may be expressed as

$$
F_{0}=S_{0}(1+(r+u-y) T)
$$

where $F_{0}$ is the fair forward price. $S_{0}$ is the current spot price, $r$ is the discount rate, $u$ is the cost of storage as a constant proportion of the spot price, $y$ is the convenience yield, and $T$ is the time to maturity of the contract. Note that a discrete-time formula is used instead of the more common continuous-time equivalent in order to be consistent with the observation discussed subsequently that wool prices varied little within a year.

Wool in the thirteenth century had very poor keeping qualities and therefore a very short shelf life. Lloyd (1973, p3) notes that "when a clip had to be held over from one year to the next it was often sold at a lower price than fetched by new wool." Additionally, while the cost of storage would probably not have been significant as many abbeys had such facilities, in the cases that we are interested in there would have been no incentive to hold the wool back. Even if the current market price is below that which had been expected or that likely to prevail in the future, the monasteries had already agreed the prices that will be received through the contracts. Given the monasteries' 
precarious financial positions, it would have made no sense for them to store wool when it could have been used to generate cash immediately. There is strong evidence in the literature, that medieval wool would have been almost valueless after a year. For example, a plea dated July 1299 (TNA E 13/22 m. 70d.) between William Cause of Lincoln and Everard de Sancto of Douai, concerning a contract for delivery of wool between 1290-96 suggests that because the latter merchant did not collect the wool from the abbot for the final four years of the agreement, it totally rotted. ${ }^{16}$ Therefore, while it would not be possible for us to separate out the storage cost, and the convenience yield parts of the interest rate ( $u$ and $y$ ), we would argue that $u$ would be small and $y$ would be negligible. We do have evidence that the monasteries had large woolsheds at their disposal and therefore that the pure storage costs of holding wool are likely to have been small. A strong indicator of this is that the monks also sold "collecta" wool, where they gathered together, cleaned and stored cheaper grade wool from small local growers. The fact that they were able to do this profitably suggests that large storage facilities were available relatively cheaply.

As stated above, it is the case that for the vast majority of contracts, $F_{0}$ is substantially below $S_{0}$, and therefore employing equation (1) to back out the implied interest rate $(r+u-y)$ will yield a negative rate. The formula cannot apply in this case as a result of the loan component of the transaction and the associated up front payment. Therefore, in order to estimate the interest rate for the transaction, an alternative approach that focuses on the loan component must be employed. Following Eldridge and Maltby, we use a present value calculation and then we solve for the interest rate. To give one illustration of how this operates, consider the contract signed on 16 October $1288^{17}$ by John de Bosco and Edmund Trussel with the Riccardi of Lucca for the supply of two sacks of good wool per year at the feast of the Nativity of St John the Baptist (24 June) for three years starting in 1289. The merchants paid the full eleven marks per sack in advance upon signing the contract. The present value calculation would be

\footnotetext{
${ }^{16}$ Everard claimed his non-appearance from 1293-96 was due to a trade embargo and blockade of the North Sea.

${ }^{17}$ TNA E $159 / 62$, rot. 14 .
} 


$$
a d v=\frac{P_{1289}}{(1+r)^{t_{1}}}+\frac{P_{1290}}{(1+r)^{t_{1}+1}}+\frac{P_{1291}}{(1+r)^{t_{1}+2}}
$$

where $a d v$ is the advance payment received, i.e. the full payment of 11 marks (1760d) per sack $\times 6$ sacks, $t_{1}$ is the time from enrolment (contract signing) to due delivery for the first batch. This equation would then be solved for $r$. Note that the prices, $P_{1289} \ldots P_{1291}$ to be employed in the present value calculation would not be the prices specified in the contract, since using these would give a calculated interest rate of zero. Given the illegality of usury at the time, the transaction would have shown an implicit rather than explicit return for the merchants on lending the money. Instead, following Eldridge and Maltby, we employ the spot prices that actually prevailed on those dates.

\subsection{Determining the "Spot" Price of Wool}

In order to be able to calculate the implied interest rate underlying these transactions, it is necessary to know the prevailing "spot" price, or the price that would have been paid on a particular date for immediate delivery of wool. Unfortunately, this information is considerably harder to obtain than that for advance delivery because most straightforward swaps of cash for wool would not have been recorded. The classic source of spot prices is Lloyd (1973), who provides information on wool prices by year and by region. But a casual examination of his Table 1 suggests significantly lower valuations than those in the forward contracts we consider. Munro (1978), indeed, has argued that Lloyd's prices for 1294 are only 57\% of the mean English abbey wool price in the Exchequer Schedule of that year. This schedule, arising from the seizure of the goods of foreign merchants by Edward I, details the merchant inventories of wool confiscated by the king and also provides the spot prices for monastic wool prevalent in England and Wales in that year. ${ }^{18}$ Munro argues that Lloyd's prices are biased for that year since they are based on only five districts that produced relatively low quality wool.

\footnotetext{
${ }^{18}$ TNA E 101/126/7. Also available in a transcribed and translated form in Bell, et al (2006), Appendix I.
} 
However, whilst Lloyd's prices for 1294 are lower than those for previous years, none of them are close to those contained in the forward contracts. The prices contained in Munro, drawn from the Exchequer Schedule, look more plausible, but also have drawbacks. Most importantly, the data are only available for this single year, and not for the range of years that we wish to consider. The other prices presented in Munro, Table 1 are obtained from a further two sources: the Douai Schedule of prevailing English wool prices on the continent (c. 1270) and the Pegolotti Schedule, a ready reckoner of monastic wool production and prices around the turn of the fourteenth century compiled by a Florentine merchant with experience of English market conditions. ${ }^{19}$ The average difference between the Douai and Pegolotti schedules is around 8\%, while the Exchequer Schedule averages about $13 \%$ less for English wool. These differences are attributable to the costs of transportation, taxes and so on since the Douai and Pegolotti Schedules refer to prices in Flanders for variable dates. We will therefore adopt the Exchequer Schedule as our point of reference, representing the spot wool price in 1294.

We then make an adjustment to these prices based on the difference between the average price for good quality wool that prevailed in 1294 according to Lloyd (£3.86) and Lloyd’s price for good quality wool in the year that the contract was enrolled and in that region. To give an illustration, suppose that the Exchequer schedule price for wool from a particular abbey is 1200d and the contract is enrolled in 1275 . The mean wool price from Lloyd for that year in that region is $£ 4.15$, and so the adjusted price that we use as a proxy for the price that would have prevailed for immediate delivery of good wool in 1275 is $1,200 \mathrm{~d} \times £ 4.15 / £ 3.86=1,290 \mathrm{~d} .^{20}$

We are thus implicitly assuming that while Lloyd's average prices are too low, the proportional variations in prices between regions and across years are accurate. We will also assume that prices

\footnotetext{
${ }^{19}$ The dating of the Pegolotti Schedule is controversial: Munro (1978, pp. 129-135).

${ }^{20}$ For simplicity, when analysing the contracts, we subsequently convert all values into old pence (d). To remind readers of the conversion rates, one shilling $=12 \mathrm{~d}, £ 1=240 \mathrm{~d}, 1$ mark $=160 \mathrm{~d}$.
} 
did not vary within a year. According to Lloyd (1973, p5), this assumption held in reality since both the supply of and the demand for wool were known by the time that the sheep were to be sheared.

A number of contracts were necessarily excluded from this part of the statistical analysis. A contract had to be removed from the sample if it did not specify the wool quality, if the abbey was not listed in the Exchequer Schedule and there was no nearby comparator abbey, if there were ambiguities in the contract (for example, if a contract states that 12 sacks are to be delivered but the sum of the sacks of good wool, middle wool and locks is 14 sacks), if a price per sack is not quoted, or if no delivery date is specified in the contract, or if there is no advance payment. The statistical analysis focuses mainly on good wool since it is this grade that is discussed in the Exchequer schedule. However, the spot prices for lower grades of wool are scaled down for inclusion in the calculation this is discussed in greater detail below. We also removed from the analysis any contracts with a lifetime of less than 9 months, to exclude any contracts covering wool from the same season. Finally, for the calculation of interest rates (but not for the other statistical analysis), we only examine contracts where the advance payment constituted the entire amount to be remitted by the merchants to the abbots. Sometimes, the contracts make vague references to complex miscellaneous payments. This restriction was imposed to avoid the need to make assumptions about when the additional payments from the merchants would be made during the lifetime of the contract, unless the contract also specified this, in which case it was included in the analysis.

\subsection{Wool Quality and Its Effect on Price}

An examination of the contracts clearly shows that the merchants were sensibly willing to pay more for wool of higher quality. Wool quality varied substantially by region according to the breed of sheep and the quality of the land for grazing. In the contracts that we have investigated, medieval wool was classified into four broad categories: good wool (highest quality, fine wool), middle wool, locks, and second locks (locks are the poor quality, coarser, loose wool). A casual examination of 
the contracts that we have found suggests that middle-grade wool is typically worth about two thirds that of good wool, with locks worth around half that of good wool. More precisely, averaging over all of the relevant contracts in our sample, middle-grade wool forward prices specified in the contracts are $68 \%$ of good wool prices. Similarly, locks are worth $50 \%$ of good wool prices. Finally, collecta wool (good wool that an abbey would collect in its stores from other local non-monastic producers to be sold together) is worth $83 \%$ of non-collecta good wool. Since spot price data are only available for good quality wool, we use these percentages to convert the good wool spot prices in the present value calculations to obtain appropriate spot prices for lower grades of wool.

There is significant evidence in these contracts that religious orders obtained more for their wool than non-monastic sellers. The average discount of the contract price per sack from the prevailing market price is $18 \%$ for religious orders but $25 \%$ for others. It also appears that some religious orders were systematically able to obtain more for their wool than others. It is commonly thought that Cistercian wool was particularly highly valued because it was not only of good quality, but it was also subjected to a highly skilled preparation before delivery. Indeed, in sixty contracts predominantly, though not exclusively, made with Cistercian monks, merchants demanded thorough washing, drying, sorting, weighing and specialized packaging of the purchased wool, time-consuming and costly processes in which Cistercian abbeys excelled. The Exchequer Schedule $^{21}$ explicitly states the expenses of the wool dresser, which usually amounted to around $2 \%-4 \%$ of the total value of the wool.

\subsection{Risks to the Counterparties}

In the context of futures contracts, where there would be no counterparty risk, the appropriate discount rate would be the risk-free rate, but in the present context it is likely that not only did such risks exist, but there could also have been differential levels of risk between the merchants and the

\footnotetext{
${ }^{21}$ TNA E101/126/7, mm.14, 17
} 
abbots. The lack of storability of medieval wool beyond a few months implies that it would not have been possible to hedge a long dated forward position. Therefore, both the suppliers of wool and the purchasing merchants would have faced risks when entering into a contractual agreement for the exchange of wool for cash, and these risks are likely to have been reflected in the prices paid or received for the wool.

On the abbots' side, the only real risk was that they had contracted to supply something that they later found themselves unable to deliver. Since the abbots could have no idea whether their flock would be diseased in ten years time, this was a significant risk that they had no way to hedge or insure against. $^{22}$ The abbeys are unlikely to have faced any risk that the merchants would default because they had usually received much of or all of the specified money due at the time of signing the contract.

On the merchants' side, the potential risks are more numerous, but arguably less catastrophic in most cases. These risks, which are nicely summarised by Eldridge and Maltby (1993, p.44) include

- The risk of default due to disease in the sheep

- The risk of deliberate default by a dishonest monastery

- The risk of seizure of the wool by the crown, or of the imposition of taxes.

- The risk that a debt-ridden abbey will declare itself bankrupt to be taken into royal custody.

The contracts that have been investigated give some indication of whether default occurred. Of the 226 contracts documented only 49 state that the delivery was made in full. We cannot make any assumptions concerning the outcomes of those contracts that do not specify either that the delivery occurred in full or that there was a default. Therefore, the default rate appears to be about $12 \%$. However, particularly in times of widespread sheep disease, the probability of default is likely to have been much higher than this. In the case of default, the records suggest that the "recovery rate"

\footnotetext{
${ }^{22}$ Apart from entering into a forward agreement of the sort we investigate and then defaulting.
} 
for the merchants was about half of the volume of wool specified in the contract. More often, though, the king's willingness to protect ailing monasteries coupled with the merchants' desire to maintain a grip on the sources of best quality wool led in most cases of default to a renegotiation of the original contract, frequently skewed more in the merchants' favour but giving the abbot a more practical timetable for delivery. The ultimate indirect penalty, of course, could be dissolution of the monastery, although this would not help the merchants since an amount equivalent to the value of the default would be paid to the crown from monastic assets, not to the merchants. While short-term bankruptcies did occur at Flaxley, Kirkstall and Rievaulx, for example, the general pattern tended towards renegotiation and survival rather than this most severe of consequences. ${ }^{23}$

In consequence, the presence of a risk premium has not been ruled out, but given the available data, it is impossible to test explicitly for this. Interestingly, at the time of the wool forward contracts, finding a proxy for the "risk-free rate" would be impossible since the Medieval equivalent of Treasury securities, loans to the Crown, were frequently defaulted upon. Therefore, it would not be possible to separate out any "risk premium" from the base (risk-free) rate of interest within the overall interest rate implied in the transaction.

The impact on the merchant of the wool seller defaulting is unclear, and would depend on whether the merchant had already sold the wool on to a third party. Damages to cover default were sometimes specified in the terms of the contract. If he had not, the maximum potential loss would be the advance payment made, plus any foregone return on the sum that could have been earned between payment of advance and default. But if the merchant was also obliged to deliver the wool, and had to purchase the wool at the prevailing spot price, the loss could be more substantial. In summary, the possibility of one of the counterparties defaulting on the contract agreement will only affect the prices if either one party is more risky than the other or if one party would be affected

\footnotetext{
${ }^{23}$ For Flaxley and Rievaulx see Lloyd (1977, p. 290) and for Kirkstall see Barnes (1984, pp. 43-4).
} 
more adversely by a default than the other. Both parties faced risks and it is not obvious which were the greater.

One would have expected that the probability of default would be higher the longer the contract, and therefore that the merchants would have been prepared to pay less per sack for longer contracts implying a higher rate of interest on the loan component. There seems to be no evidence for this among the contracts that we studied, since the correlation between the length of the contract and the discount of the price paid per sack relative to the prevailing market price was -0.18 . Thus slightly higher prices per sack were paid on average for longer contracts, perhaps suggesting that the merchants valued a continuing supply of wool more highly than they did the additional risk. There is also evidence that merchants were sometimes willing to pay inflated prices in a deliberate attempt to preclude rival merchants from obtaining wool supplies.

\subsection{Were the Forward Prices Specified in the Contracts Unbiased and Were the Markets Efficient?}

A further issue worthy of investigation is the extent to which the forward rate unbiasedness (FRU) hypothesis held in the medieval wool market. This hypothesis states that (in the absence of transactions costs and other impediments to the effective functioning of the markets), the forward price should be an unbiased predictor of the subsequent spot price. Such analyses have been conducted extensively in the context of exchange rates (see, for example Hansen and Hodrick, 1980 or Goodhart et al., 1992). Clearly, however, the wool market is unlikely to have been frictionless and available data are limited, but it is nonetheless of interest to investigate whether this relation holds using a regression model of the following type ${ }^{24}$

$$
S_{t+k}-F_{t, k}=a+b_{1}\left(S_{t}-F_{t-k, t}\right)+c_{1}\left(S_{t-1}-F_{t-k-1, t-1}\right)+u_{t+k}
$$

\footnotetext{
${ }^{24}$ The variables in this equation are often employed in their logarithmic forms, but for ease of interpretation, we use the levels here.
} 
where $S_{t+k}$ is the spot price prevailing at time $t+k, F_{t, k}$ is the forward price for $k$ periods ahead available at time $t$, and so on, and $u_{t}$ is an error term. ${ }^{25}$ Some researchers may suggest that significance of the parameters $b_{1}$ or $c_{1}$ in equation (3) is not indicative of inefficiency since these do not imply an unexploited arbitrage opportunity, but we would argue that if the market is functioning properly, there should be no information from previous forecast errors that could be used to predict the next period forecast error. If the market is efficient, these forecast errors should be uncorrelated.

A natural joint hypothesis to test is $\mathrm{H}_{0}: a=0$ and $b_{1}=0$ and $c_{1}=0$. If equation (3) is estimated using OLS, then this joint hypothesis can be examined using an $F$-test. This hypothesis represents the restriction that the deviation of the forward rate from the realised rate at time $t+1$ should have a mean value insignificantly different from zero $(a=0)$ and it should be independent of any information available at time $t\left(b_{1}=0\right.$ and $\left.c_{1}=0\right)$. This hypothesis represents a joint test of FRU and of the efficiency of the spot and forward markets, although simpler test of FRU alone would simply focus on $a$, with both of the other parameters set to zero. We employ a pooled sample of data from 67 different contracts, some with only one batch for forward delivery and others with up to 20 , totalling 277 observations on the forward prices from the contracts and spot prices relating to those delivery dates.

It should already be evident from the analysis above that in modern financial parlance, the forward price will be a downwardly biased predictor of the future spot price, and therefore $a$ would be expected to be significantly positive and thus there will be normal backwardation. ${ }^{26}$ However, it is still of interest to consider whether the markets were efficient, although it is only possible to conduct such an examination using the lagged spot prices, and not on the lagged difference between the spot and forward prices, $\left(S_{t}-F_{t-k, k}\right)$. The latter quantity is not available since our sample

\footnotetext{
${ }^{25}$ Sometimes the test regression is instead conducted with the dependent variable being the change in the spot price from time $t$ to time $t+k$.

${ }^{26}$ However, this arises from the loan component of the transaction rather than as compensation for speculators as may be the case for modern commodity forwards.
} 
involves a series of forward prices that are not continuous through time. We are able to run a regression including this variable with a lead of one period as the regressand where each observation arises from a separate contract rather than the same contract at different points in time, but not also as a regressor since the "lagged" forecast error would be from a different contract. Thus we consider lagged influences of the change in the spot price on $S_{t+k}-F_{t, k}$ since we have a series of time-adjusted prices for the wool from each abbey or region. We will term $S_{t+k}-F_{t, k}$ the "forecast error" to avoid confusion with the basis. ${ }^{27}$

We first run a regression of $S_{t+k}-F_{t, k}$ on a constant only to determine the average value of this dependent variable, and we obtain $\hat{a}=416.78$, with a standard error of 49.36 ( $p$-value 0.000 ). Thus, ignoring all other influences, the typical price per sack received by the sheep breeders is $417 \mathrm{~d}$ lower than they would have received on the open market. Next, we reduce the sample to consider only the first year of any contract (thus setting $k=1$ in equation 2 ). We do this firstly because the forward prices per sack in the agreements are almost always identical for the life of the contract, and secondly, because we want to ensure that when we test for efficiency, we are only employing current and lagged prices that would have been in the information sets of those forming the agreements. This reduces the number of available observations to 63 . We thus run a regression of the following form estimated using OLS

$$
S_{t+1, i}-F_{t, 1, i}=a+b_{1}\left(S_{t, i}-S_{t-1, i}\right)+b_{2}\left(S_{t-1, i}-S_{t-2, i}\right)+u_{t+1, i}, \quad i=1, \ldots, 63 .
$$

where $S_{t+1, i}$ denotes the spot price for contract $i$ prevailing at time $t+1$, and $F_{t, 1, i}$ is the forward price for contract $i$ and for delivery 1 period (year) ahead, made at time $t$. We also want to examine formally the relationship between the forecast error and the length of the contract and between the forecast error and the size of the contract (the total number of sacks to be delivered). This leads to the regression

\footnotetext{
${ }^{27}$ The basis is the difference between the current spot price and the forward price for delivery in the future, that is, $S_{t}-F_{t, k}$.
} 


$$
S_{t+1, i}-F_{t, 1, i}=a+b_{1}\left(S_{t, i}-S_{t-1, i}\right)+b_{2}\left(S_{t-1, i}-S_{t-2, i}\right)+b_{3} \text { sacks }_{i}+b_{4} \text { length }_{i}+u_{t+1, i}
$$

Finally, we are also interested in determining the impact of the monastic order on the forecast error. Unfortunately, we have insufficient number of contracts for the individual orders to be able to examine this within a regression framework, so we instead consider the impact of belonging to any religious order. We achieve this by repeating regression (5) but only for contracts where the seller was a member of a religious order. This further reduces the number of observations to $37 .^{28}$

\section{Results}

\section{$\underline{5.1 \text { Results of Interest Rate Calculations }}$}

Table 2 gives summary information and calculated interest rates for the contracts that we examined. All prices quoted in the table are in old pence. It is not immediately obvious whether the spot prices used in the interest rate calculations should relate to those prevailing at the times when the wool was to be delivered, or whether they should be the prices quoted at the time that the contract was initially signed. A present value relationship would usually use the former, while the latter also makes sense in this case in order to use only the information that would have been available to the counterparties at the time when they were establishing the contract details. We employ (separately) both methods for determining the spot prices, and this almost always makes little difference to the calculated interest rates.

The fourth and sixth columns of Table 2 show the total number of sacks to be delivered over the life of the contract, and the number of sacks per year respectively, while the fifth column gives the delivery dates for each batch of wool. The third column from the right of the table shows the forward prices per sack as specified in the contracts, and the last two columns give the interest rates

\footnotetext{
${ }^{28}$ An alternative approach to determining whether the spot and forward markets were informationally efficient would be to examine whether there existed any lead-lag relationships between the spot and forward prices, although this is not possible for our dataset since we do not have an evenly spaced time-series of forward prices.
} 
for each spot price measure, calculated by solving the present value relationships of the form given in equation (2) to find $r$ for each contract.

Of course, there will be situations where our spot prices are somewhat inaccurate (for example, if Lloyd's prices are based on a very small sample for a particular region in a particular year), or where the spot prices changed substantially between when the contract was enrolled and when the wool was due for delivery. There may also be case-specific details of which we are unaware (for example, a monastery being unable to secure a good price for its wool owing to previous defaults). These factors may result in negative calculated interest rates, which we set to zero in the table, or implausibly high rates of interest. Examining the last two columns of Table 2, there are evidently some zero rates and some implausibly high rates. But for the majority of contracts that we investigated, and that were amenable to this analysis, the implied rates of interest are not only plausible, but are also in accordance with other historical studies detailing interest rates on alternative types of transactions at that time. For example, Eldridge and Maltby cite Mate (1973), who studied loans to Canterbury cathedral priory, where interest rates ranged from $15 \%-24 \%$ per annum, and Gilchrist (1969, p.298), who suggested that loans to the church commanded interest rates of $15 \%-38 \%$. Employing the spot prices that prevailed when the contract was signed for the whole lifetime of the contract gives a median interest rate per annum of $22 \%$; using the spot prices that prevailed at each delivery date gives a median rate of $18 \%$ per annum; the majority of implied interest rates are between $10 \%$ and $40 \%$.

Eldridge and Maltby's study used data from a contract made between the Fountains Abbey in Yorkshire and a consortium of Florentine merchants, enrolled on 15 October $1276^{29}$ (the second contract on our list in Table 2). They calculated interest rates of between $40 \%$ and $60 \%$ per annum, depending on assumptions made concerning the spot rate. However, they used a different approach

\footnotetext{
${ }^{29}$ TNA C 54/93, m. 3d.
} 
to determining the spot prices (that we would argue is less accurate than the method employed here). They assumed that the time until delivery of the first batch of wool was a year when in fact it was nine months, and they did not allow for the fact that collecta wool was to be delivered under the contract rather than the monastery's own wool, whereas we account for this. Our calculated interest rates for this contract are $17 \%$ and $22 \%$ (depending on the dates used to determine the spot prices), figures much closer to those usually quoted for financial transactions during the thirteenth century.

\section{$\underline{5.2 \text { Results of Wool Market Efficiency Tests }}$}

Table 3 presents the results of the test regressions for market efficiency. Comparing the sizes of the intercept parameters across the regressions for all sellers and for monastic sellers only, it is again evident that the latter obtained a worse deal, with heavier discounts relative to the high price that their good wool could have obtained if sold in the year it was sheared. The sizes and statistical significances of the intercepts in all four regressions are clear evidence that the contract forward prices were biased, but were the markets efficient? That is, was there information that would have been available to the counterparties at the time the contract was signed that was not incorporated into the deal? Although they all have the same positive sign, none of the one period lagged spot price changes are significant in the regressions, and only the two period lagged price changes are significant in the "all seller" regressions. The final column of Table 3 presents the F-test statistics for examining the joint null hypothesis that $b_{1}=b_{2}=0$. As can be seen, for all sellers, the statistic is only significant at the $10 \%$ level, while for monastic sellers only, it is not even significant at the $20 \%$ level. This can be interpreted as suggesting that only to a limited degree could old information from the spot market have been used to predict the subsequent forecast error. It would therefore be concluded that, by comparison with studies on modern day financial markets, the Medieval wool markets were fairly efficient. In particular, there is no evidence that the forecast error could have been predicted using this stale information when the sellers were abbots. 
Comparing these results with existing studies on the efficiency of modern wool markets suggests that broadly the same conclusions were reached. The efficiency of the Australian wool market is investigated by Praetz (1975) using a number of statistical tests applied to daily data. His results suggest that the returns are essentially independent from one another, indicating that from this perspective, the market is indeed efficient. Only a spectral analysis indicates a possible departure from randomness, but this is attributed to likely seasonal patterns in the returns. Goss (1987), on the other hand, employs a similar approach to that used here based on a Hansen and Hodrick (1980) regression of the Sydney wool futures price forecasting error on previous forecasting errors from Sydney and other futures markets. He finds some evidence of inefficiency at the 2 month lead horizon (i.e. where the time to maturity of the futures contract is 2 months), but this mispricing is corrected when only one month to maturity remains. This inefficiency, according to Goss, may be explained by lower trading volume over the sample period than had previously been the case, leading to slower price adjustment.

More recently, Goss (1990) and Graham-Higgs et al. (1999) also both examine the Australian wool spot-futures price relationship. Goss (1990) employs a simultaneous equations model that allows for inventory sizes and the roles of speculators and hedgers. He finds that information from the model is useful for predicting subsequent spot prices, but urges caution in interpreting this as evidence for market inefficiency. Graham-Higgs et al. use an error correction model, finding that wool spot and futures prices are cointegrated, but that the speed of adjustment following deviations from equilibrium is slow, particularly for longer dated futures. Thus, even for these modern contracts that are highly liquid and tradable on a formal exchange, the evidence for efficiency is mixed. When considered in this light, the medieval wool forward market was remarkably well-functioning and orderly. 
Finally, there seems to be virtually neither a relationship between the contract size (total number of sacks to be delivered) and the forecast error, nor between the length of the contract period and the forecast error. Sellers of larger quantities who were to deliver quickly (i.e. short contracts) would generate the smallest forward pricing discounts relative to market prices, as one would expect. However, the small sizes of the coefficients and their lack of statistical significance mean that we should not read too much into these results.

\section{Conclusions}

Our study has documented the existence of a large number of agreements for the advance sale of wool, formed mainly between Italian merchants and monastic orders in England. We have calculated the interest rates implied in these transactions to typically be of the order $10-40 \%$, and we have investigated the informational efficiency of the market, finding limited evidence of predictability in the forecast errors. We also conducted an examination of the efficiency of the medieval English wool spot and forward markets, finding little evidence of inefficiencies in the sense that stale information could be used to predict future market outcomes. This paper adds to the growing body of evidence that those transacting in the medieval economy were much more financially aware than modern commentators give them credit for, and thus it seems that "modern finance" is perhaps not so modern after all, and that valuation formulae developed in the past few decades were implicitly in use over 700 years ago.

Our research suggests several potentially fruitful avenues for further study. First, it would be of interest to examine in greater detail the financial positions of the abbeys. Was there, for example, a relationship between the state of their finances and the forward price discount? It may be that knowledgeable merchants were able to exploit the monasteries in trouble that were the most desperate for cash. Second, is there a relationship between the likelihood of default and the size of the forward price discount? Clearly, monasteries that had sold their wool the most cheaply relative 
to prevailing prices would have the strongest incentives to renege on the deal when the wool became available. Finally, the existence of the advance contracts for the sale of wool that we have investigated appears to be a historically unique phenomenon as they are confined to a short period at the close of the thirteenth century. As well as investigating other aspects of these contracts in greater detail, such as the credit risk that the merchants faced when they made up-front payments to the monasteries, future research may investigate why the forward agreements died out almost as quickly as they arose.

\section{References}

Bakken, H.H., 1960. Historical Evaluation and Legal Status of Futures Trading in American Agricultural Commodities. Futures Trading Seminar, 1, Mimir, Madison.

Bakken, H.H., 1966. Futures Trading - Origin, Development, and Economic Status. Futures Trading Seminar, 3, Mimir, Madison.

Barnes, G., 1984. Kirkstall Abbey, 1147-1539: An Historical Study. Leeds: Publications of the Thoresby Society, LVII, no. 128.

Bell, Adrian R., Brooks, Chris, and Dryburgh, Paul, 2006. Advance Contracts for the Sale of Wool c. 1200 1327. List and Index Society. also accessible at the UK Data Archive, study number 5325: www.data-archive.ac.uk

Bigwood, G., 1930. Un marché de matières premières : laines d'Angleterre et marchands italiens vers la fin du 13e siècle. Annales d'Histoire Économique et Sociale 2, 193-209.

Carus-Wilson, E.M. and Coleman, O., 1963. England's Export Trade 1275-1547. Oxford University Press.

Denholm-Young, D., 1937. Seignorial Administration in England. London.

Eldridge, R.M and Maltby, R., 1992. On the Existence and Implied Cost of Carry in a Medieval English Forward/Futures Market. The Review of Futures Markets 11(1), 36-49.

Fryde E.B., 1988. William de la Pole, Merchant and King’s Banker. London.

Gilchrist, J., 1969. The Church and Economic Activity in the Middle Ages. Macmillan, London.

Goldthwaite, R.A., 1985. Local Banking in Renaissance Florence. Journal of European Economic History 14(1), 5-55.

Goodhart, C.A.E., McMahon, P.C. and Ngama, Y.L., 1992. Does the Forward Premium/Discount Help to Predict the Future Change in the Exchange Rate? Scottish Journal of Political Economy 39, 129-139.

Goss, B.A., 1990. The Forecasting Approach to Efficiency in the Wool Market. Applied Economics 22, 973993.

Goss, B.A., 1987, Wool Prices and Publicly Available Information. Australian Economic Papers 26, 225236. 
Graham-Higgs, J., Rambaldi, A., and Davidson, B., 1999. Is the Australian Wool Futures Market Efficient as a Predictor of Spot Prices. Journal of Futures Markets 19(5), 565-582.

Hansen, L.P. and Hodrick, R.J., 1980. Forward Rates as Optimal Predictors of Spot Rates: An Econometric Analysis. Journal of Political Economy 88, 829-853.

Hunt, E.S., 1990. A New Look at the Dealings of the Bardi and Peruzzi with Edward III. Journal of Economic History 50, 149-162.

Kairys Jr., J.P. and Valerio III, N., 1997. The Market for Equity Options in the 1870's. Journal of Finance 52(4), 1707-1723.

Kohn, M., 1999. Risk Instruments in the Medieval and Early Modern Economy. Department of Economics, Dartmouth College, Working paper 99-07.

Kroll, S. and Paulenoff, M.J., 1993. The Business One Irwin Guide to the Futures Markets. Business One Press, Homewood, Illinois.

Lloyd, T.H., 1973. The Movement of Wool Prices in Medieval England. Economic History Review Supplement 6, Cambridge University Press.

Lloyd, T.H., 1977. The English Wool Trade in the Middle Ages. Cambridge University Press.

Mate, M., 1973. The Indebtedness of Canterbury Cathedral Priory 1215-1295. Economic History Review Second Series, 26(2), 183-197.

Munro, J., 1978. Wool Price Schedules and the Qualities of English Wools in the Latter Middle Ages c. 1270-1499. Textile History 9, 118-169.

Postan, M.M., 1973. Medieval Trade and Finance, Cambridge University Press.

Power, E., 1941. The Wool Trade in English Medieval History. Oxford University Press.

Praetz, P.D., 1975. Testing the Efficient Markets Theory on the Sydney Wool Futures Exchange. Australian Economic Papers 14, 240-249.

Swan, E.J. 2000. Building the global market: A 4000 year history of derivatives. Kluwer, Dordrecht

Whitwell, R. J., 1904. English Monasteries and the Wool Trade in the 13th Century. Vierteljahrschrift fur Sozial-und-Wirtsschaftsgeschichte, 2, 1-33.

Williams, J. (1986) The Economic Function of Futures Markets. Cambridge University Press. 
Table 1: Wool Price Summary Statistics

\begin{tabular}{cc}
\hline Statistic & Value \\
\hline mean & 4.615 \\
variance & 0.585 \\
skewness & 0.216 \\
kurtosis & 0.109 \\
$\mathrm{AR}(1)$ & 0.762 \\
$\mathrm{AR}(2)$ & 0.755 \\
$\mathrm{AR}(3)$ & 0.518 \\
DF-statistic & -2.982
\end{tabular}

Notes: $\operatorname{AR}(j)$ is the autocorrelation coefficient at lag $j$; DF is the Dickey-Fuller test, with $5 \%$ critical value -2.86 . 
Table 2: Results of Interest Rate Calculations

\begin{tabular}{|c|c|c|c|c|c|c|c|c|c|}
\hline $\begin{array}{c}\text { Estimated date of } \\
\text { enrolment }\end{array}$ & $\begin{array}{c}\text { Spot at } \\
\text { date wool } \\
\text { due } \\
\end{array}$ & $\begin{array}{l}\text { Spot at } \\
\text { date } \\
\text { contract } \\
\text { signing }\end{array}$ & $\begin{array}{c}\text { Total sacks } \\
\text { over } \\
\text { contract } \\
\end{array}$ & $\begin{array}{c}\text { Due dates for } \\
\text { delivery }\end{array}$ & $\begin{array}{c}\text { Sacks } \\
\text { each year }\end{array}$ & Quality & $\begin{array}{c}\text { Price } \\
(\mathrm{d} / \text { sack })\end{array}$ & $\begin{array}{c}\text { Interest rate - } \\
\text { spot at wool } \\
\text { due }\end{array}$ & $\begin{array}{c}\text { Interest rate - } \\
\text { spot at } \\
\text { contract } \\
\text { signing } \\
\end{array}$ \\
\hline \multirow[t]{2}{*}{15 October 1276} & 2904 & 3022 & 62 & 9 July 1277 & 17 & Collecta & 1800 & 22 & 17 \\
\hline & 3606 & 3022 & & 9 July 1278 & 17 & Collecta & 1800 & & \\
\hline \multirow[t]{2}{*}{5 February 1280} & 2338 & 2338 & 53 & 9 July 1280 & 25 & Good & 2000 & 0 & 0 \\
\hline & 2109 & 2338 & & 9 July 1282 & 28 & Good & 2000 & & \\
\hline \multirow[t]{2}{*}{20 May 1280} & 1802 & 3117 & 20 & 24 June 1280 & 10 & Good & 1600 & 31 & 448 \\
\hline & 1932 & 3117 & & 24 June 1281 & 10 & Good & 1600 & & \\
\hline 9 October 1281 & 2109 & 1462 & 3 & 2 July 1282 & 3 & Good & 1760 & 22 & 0 \\
\hline 9 October 1284 & 2882 & 3730 & 10 & 9 July 1285 & 10 & Good & 2400 & 28 & 28 \\
\hline \multirow[t]{2}{*}{8 July 1286} & 2174 & 2126 & 23 & 24 June 1287 & 13 & Collecta & 2080 & 0 & 0 \\
\hline & 2193 & 2126 & & 24 June 1288 & 10 & Collecta & 2080 & & \\
\hline 12 May 1287 & 2343 & 2268 & 11 & 9 July 1289 & 11 & Good & 2400 & 0 & 0 \\
\hline 25 June 1287 & 2288 & 2268 & 30 & 9 July 1288 & 30 & Good & 1600 & 45 & 44 \\
\hline \multirow[t]{2}{*}{27 June 1287} & 2288 & 1323 & 19 & 24 June 1288 & 13 & Good & 1760 & 30 & 30 \\
\hline & & & & 24 June 1288 & 6 & Good & 1760 & & \\
\hline \multirow[t]{2}{*}{13 October 1287} & 2288 & 2268 & 26 & 9 July 1288 & 10 & Collecta & 1920 & 0 & 0 \\
\hline & 2288 & 2268 & & 24 June 1288 & 8 & Good & 2560 & & \\
\hline 27 November 1287 & 1350 & 1512 & & 2 February 1292 & 80 & Collecta & 1000 & & \\
\hline \multirow[t]{3}{*}{16 October 1288} & 2148 & 2097 & 6 & 24 June 1289 & 2 & Good & 1760 & 14 & 11 \\
\hline & 2275 & 2097 & & 24 June 1290 & 2 & Good & 1760 & & \\
\hline & 2120 & 2097 & & 24 June 1291 & 2 & Good & 1760 & & \\
\hline \multirow[t]{3}{*}{3 November 1288} & 2343 & 2288 & 11 & 9 July 1289 & 2 & Good & 2400 & 0 & 0 \\
\hline & 2482 & 2288 & & 9 July 1290 & 4 & Good & 2400 & & \\
\hline & 2313 & 2288 & & 9 July 1291 & 5 & Good & 2400 & & \\
\hline \multirow[t]{6}{*}{27 November 1290} & 1156 & 1241 & 30 & 24 June 1291 & 5 & Good & 960 & 0 & 9 \\
\hline & 1012 & 1241 & & 24 June 1292 & 5 & Good & 960 & & \\
\hline & 1092 & 1241 & & 24 June 1293 & 5 & Good & 960 & & \\
\hline & 960 & 1241 & & 24 June 1294 & 5 & Good & 960 & & \\
\hline & 669 & 1241 & & 24 June 1295 & 5 & Good & 960 & & \\
\hline & 900 & 1241 & & 24 June 1296 & 5 & Good & 960 & & \\
\hline \multirow[t]{2}{*}{9 October 1292} & 1820 & 2868 & 11 & 15 July 1293 & 6 & Good & 1920 & 6 & 62 \\
\hline & 1600 & 2868 & & 15 July 1294 & 6 & Good & 1920 & & \\
\hline 29 October 1292 & 2730 & 2531 & 10 & 22 July 1293 & 10 & Good & 2240 & 31 & 18 \\
\hline \multirow[t]{2}{*}{7 April 1293} & 2730 & 3457 & 12 & 9 July 1293 & 6 & Good & 1280 & 231 & 510 \\
\hline & 2400 & 3457 & & 9 July 1294 & 6 & Good & 1280 & & \\
\hline
\end{tabular}


Table 3: Regression Results of Tests for Market Efficiency

Model: $S_{t+1, i}-F_{t, 1, i}=a+b_{1}\left(S_{t, i}-S_{t-1, i}\right)+b_{2}\left(S_{t-1, i}-S_{t-2, i}\right)+b_{3}$ sacks $_{i}+b_{4}$ length $_{i}+u_{t+1, i}$ Panel A: All Sellers

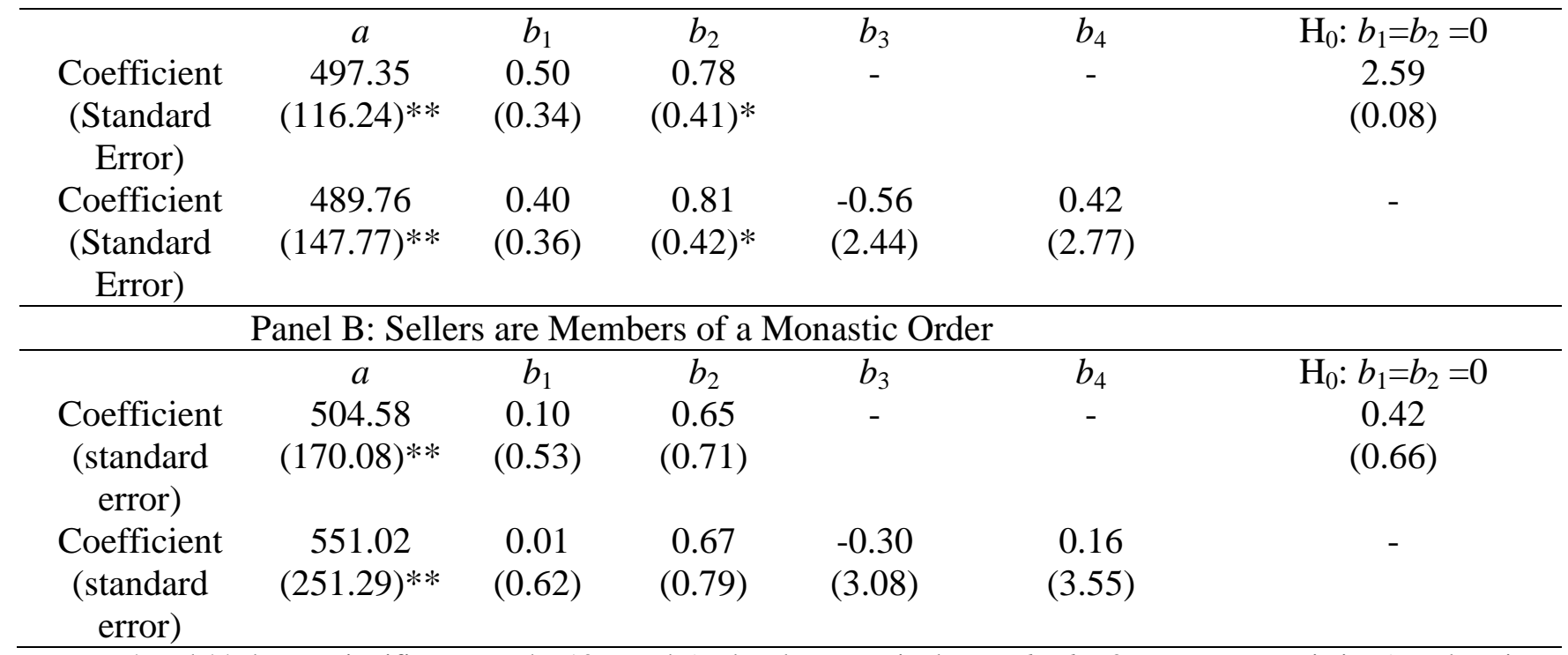

Note: $*$ and $* *$ denote significance at the $10 \%$ and $5 \%$ levels respectively. $\mathrm{H}_{0}: b_{1}=b_{2}=0$ presents F-statistics (p-values in parentheses) for this efficiency test. 